\title{
Iktikad Tidak Baik dalam Pendaftaran dan Model Penegakan Hukum Merek di Indonesia
}

\author{
Mukti Fajar ND., Yati Nurhayati, dan Ifrani \\ Fakultas Hukum Universitas Muhammadiyah Yogyakarta \\ Jln. Lingkar Selatan Taman Tirto Kasihan Bantul Yogyakarta \\ Fakultas Hukum Universitas Islam Kalimantan Muhammad Arsyad Al-Banjary \\ JIn. Adhiyaksa No. 2, Kayu Tangi, Sungai Miai, Banjarmasin Utara, Sungai Miai, \\ Banjarmasin Utara, Kota Banjarmasin, Kalimantan Selatan 70123 \\ Fakultas Hukum Universitas Lambung Mangkurat \\ Jln. Brigjen H. Hasan Basri No.3, RW.02, Pangeran, Banjarmasin Utara, Kota \\ Banjarmasin, Kalimantan Selatan 70124 \\ muktifajar2017@gmail.com; nurhayati.law@gmail.com; ifrani99@gmail.com
}

\section{Received: 28 Mei 2018; Accepted: 23 Juli 2018; Published: 5 Nopember 2018}

DOI: 10.20885/iustum.vol25.iss2.art1

\begin{abstract}
Trade mark not only functions as an identity but also contains economic value so there are many efforts regarding bad-faith trademark registration. This study aimed to find the concept of bad-faith registration and to know the law enforcement in Indonesia. This was a normative legal research, with statute approach, conceptual approach, and case approach. The results of the study showed that: first, the concept of badfaith has been regulated in Trademark Law Number 19 of 1992, Trademark Law Number 15 of 2001 and Law Number 20 of 2016. The concept of bad-faith is when an applicant is reasonably suspected to register his trade mark improperly and dishonestly to imitate, copy, or follow the trade mark of other parties for the interests of his business, create unfair business competition atmosphere, deceive, or mislead consumers. Second, the law enforcement on bad-faith trade mark registration is carried out by (a) rejecting the trade mark since registration process; (b) removal of trade mark by trade mark owners, government (ministers) or third parties; (c) revocation of trade mark by lawsuit in Commercial Court.
\end{abstract}

Keywords: Bad faith; trade mark registration; law enforcement

Abstrak

\begin{abstract}
Merek berfungsi bukan hanya identitas tapi merek juga secara ekonomi memiliki nilai sehingga banyak upaya pendaftaran merek dengan iktikad tidak baik. Tujuan dari penelitian ini untuk menemukan konsepsi itikad tidak baik dalam pendaftaran serta mengetahui penegakan hukumnya di Indonesia. Penelitian ini menggunakan metode penelitian hukum normatif, dengan pendekatan perundang-undangan (statute approach) pendekatan konseptual (conceptual approach) serta pendekatan kasus (cases approach). Hasil penelitian ditemukan: pertama, konsep itikad tidak baik telah diatur sejak Undang-Undang Merek Nomor 19 Tahun 1992, Undang-Undang Merek Nomor 15 Tahun 2001 dan Undang-undang Nomor 20 tahun 2016. Dijelaskan konsep itikad tidak baik adalah Pemohon yang patut diduga dalam mendaftarkan mereknya secara tidak layak dan tidak jujur untuk meniru, menjiplak, atau mengikuti merek pihak lain demi kepentingan usahanya menimbulkan kondisi persaingan usaha tidak sehat, mengecoh, atau menyesatkan konsumen. Kedua, penegakan hukum atas pendaftaran merek dengan iktikad tidak baik dilakukan dengan (a) penolakan merek sejak proses pendaftaran; (b) penghapusan merek oleh pemilik merek, pemerintah (menteri) atau pihak ketiga; (c) pembatalan merek dengan cara gugatan ke Pengadilan Niaga
\end{abstract}

Kata-kata Kunci : Itikad tidak baik; pendaftaran merek; penegakan hukum 


\section{Pendahuluan}

Merek, dalam lalu lintas perdagangan memiliki peranan yang sangat penting. Dengan merek, produk dapat dibedakan asal muasalnya, kualitasnya serta keterjaminan originalitasnya. Kadangkala yang membuat harga suatu produk menjadi mahal bukan produknya, tetapi mereknya. Sebuah produk akan dikenal oleh masyarakat melalui merek sebagai tanda pengenal. Dalam interaksi dan transaksi antara produsen dan konsumen, merek berperan mewakili produsen untuk hadir mencirikan diri sebagai produk yang memudahkan konsumen untuk menemukan barang atau jasa. Sehingga merek yang telah dikenal konsumen mempunyai nilai ekonomis sebagai jaminan terhadap kualitas produk tersebut.

Merek atas suatu barang perlu dilindungi karena dalam merek terkandung hak kekayaan intelektual yang dapat mendatangkan keuntungan ekonomi bagi pemilik hak merek tersebut. ${ }^{1}$ Selain itu merek juga merupakan identitas bagi suatu produk yang akan membedakan kualitas dan kriteria dengan produk lainnya. ${ }^{2}$ Merek dalam kegiatan perdagangan mempunyai fungsi sebagai product identity, mean of trade promotion, quality guarantee, dan source of origin. ${ }^{3}$

Merek sering disalahgunakan untuk menumpang ketenaran suatu produk dengan merek tertentu. Banyak pelaku usaha yang mendaftarkan merek sengaja memiripkan dengan merek dagang terkenal sebagai upaya untuk mengelabui konsumen. Hal tersebut dapat dikatakan sebagai pendaftaran merek dengan iktikad tidak baik (bad faith).Pasal 21 ayat (3) Undang Undang Merek No. 20 Tahun 2016 (UU Merek 2016) menyebutkan : Permohonan ditolak jika diajukan oleh pemohon yang beriktikad tidak baik" yang dalam penjelasannya disebutkan "Pemohon yang beriktikad tidak baik" adalah Pemohon yang patut diduga dalam mendaftarkan Mereknya memiliki niat untuk meniru, menjiplak, atau mengikuti Merek pihak lain demi kepentingan usahanya menimbulkan kondisi persaingan usaha tidak sehat, mengecoh, atau menyesatkan konsumen. ${ }^{4}$ Ketentuan ini masih banyak menimbulkan persoalan dalam pendaftaran merek karena: pertama, ketidakjelasan konsepsi mengenai pendaftaran merek dengan iktikad tidak baik, sehingga banyak pelaku usaha dengan sengaja mendaftarkan mereknya dengan meniru dengan merek lainnya. Misalnya

\footnotetext{
${ }^{1}$ Jisia Mamahit, "Perlindungan Hukum Atas Merek Dalam Perdagangan Barang Dan Jasa", Lex Privatum, Volume, 1. No. 3. Juli 2013, hlm. 90.

2 Dwi Sri Rezki Astriani, Penghapusan Merek Terdaftar, PT Alummi, Bandung, 2009, hlm. 2... lihat juga Djumhana. Muhammad dan, R. Djubaedillah, Hak Kekayaan Intelektual ,Sejarah, Teori dan Prakteknya di Indonesia, Citra Aditya Abadi, Bandung, 1997, hlm. 170.

3 Abdul Kadir Muhammad, Kajian Hukum Ekonomi Hak Kekayaan Intelektual, Citra Aditya, Bandung, 2001, hlm. 1.

${ }^{4}$ Pasal 21 ayat (3) Undang-Undang Nomor 20 Tahun 2016 tentang Merek dan Indikasi Goegrafis.
} 
Sengketa merek "LEXUS" yang diajukan oleh PT. Toyota Jidosha Kabushiki Kaisha pemakai pertama merek "LEXUS" Logo L terdaftar di Indonesia pada Direktorat Merek, dengan No: 275.609 tanggal 25 Mei 1992. PT. Toyota menggugat PT. Lexus Daya Utama sebagai pemilik merek "LEXUS" yang mendaftarkan merek pada 11 Januari 2010, no: IDM000232235 kelas 9.5

Kasus merek yang pernah ditangani Polda Jawa Tengah dan telah disidangkan perkaranya yaitu pemalsuan merek pupuk "ATONIK" dengan "ANTONIK". ${ }^{6}$ Selanjutnya, perkara antara Societe des Produits Nestle S.A. dan PT Danone Biskuits Indonesia tentang merek wafer Kit-Kat dan Chit-Chat, kemudian perkara abtara Hari Sanusi dan Frazer and Neave Limited Singapura tentang merek "100" dan "100 Plus Power". Kasus Merek Avitex dan Envitek.7 Kasus merek "Giordano" dan "Giordani" antara PT. Walton International Limited dengan Oriflame Cosmetics dan telah diputus kasasi Nomor $012 \mathrm{~K} / \mathrm{N} / \mathrm{HAKI} / 2006.8$

Kasus lain adalah merek "holiday" antara Six Continents Hotel vs. Holiday Resort Lombok milik PT Lombok Seaside. Di Pengadilan Negeri Jakarta Pusat, Six Continents Hotel menang. Namun, putusan kasasi MA menyatakan kata "holiday" tidak bisa dipatenkan karena bersifat umum, bukan milik perorangan. Kasus lain perebutan merek tekstil Sritex antara Duniatex Karanganyar dengan PT Delta Merlin Dunia Tekstil (DMDT/Duniatex). Kasus merek jam tangan Casio Keisanki Kabushiki Kaisha, pemilik merek jam tangan Edifice Casio, perusahaan asal Jepang. Dia menggugat Casio versi lokal milik pengusaha $\mathrm{K}$ Bing Ciptadi, ${ }^{9}$ dan masih banyak kasus-kasus pendaftaran merek dengan dasar itikad buruk.

Berdasarkan lembaga pengawasan dari Amerika Serikat USTR (United States Trade Representative), Indonesia masuk dalam negara empat besar terkait tingginya angka pembajakan hak kekayaan intelektual di dunia, kerugiannya bisa mencapai Rp.

\footnotetext{
${ }^{5}$ Rini Komalasari, Analisis Yuridis Terhadap Sengketa Kepemilikan Merek "Lexus" Antara Perusahaan PT. Toyota Jidosha Kabushiki Kaisa dengan PT. Lexus Lexus Daya Utama (Studi Kasus Putusan No. 194.K/Pdt/Sus/2011, https://media.neliti.com/media/publications/162016-ID-analisis-yuridis-terhadapsengketa-kepem.pdf

${ }^{6}$ Murawi Effendi, "Pengalaman Kepolisian dalam Penyidikan Pelanggaran Hak Merek”, Makalah disampaikan dalam Seminar Nasional Perlindungan Hukum Merek dalam Era Persaingan Global, kerjasama Fakultas Hukum UII, Yayasan Klinik HaKI Jakarta, dan JETRO, 3 Maret 1999. Yogyakarta: Fakultas Hukum UII.

7 Putusan Mahkamah Agung Nomor: 815 K/PDT.SUS/2012.

8 "Lewat Lima Tahun, Gugatan Pembatalan Merek Tak Bisa Diajukan", http:/ / www.hukumonline.com/berita/baca/hol14409/lewat-lima-tahun-gugatan-pembatalan-merek-tak-bisadiajukan diakses pada tanggal 14 April 2014

9 “5 Kasus Unik Sengketa Merek Dagang di Indonesia” https://news.detik.com/berita/d-1966282/5kasus-unik-sengketa-merek-dagang-di-indonesia/3 diakses tanggal 14 April 2018.
} 
65.100.000.000.000,00.10 Perjuni 2016 tercatat 33 kasus yang didominasi pelanggaran merek.11 Dalam kurun waktu 2011-2016 tercatat ada 616 perkara, merek sebanyak 274 perkara, desain industri 16 perkara, paten 7 perkara dan rahasia dagang 3 perkara. ${ }^{12}$ Dapat dilihat dalam tabel berikut :

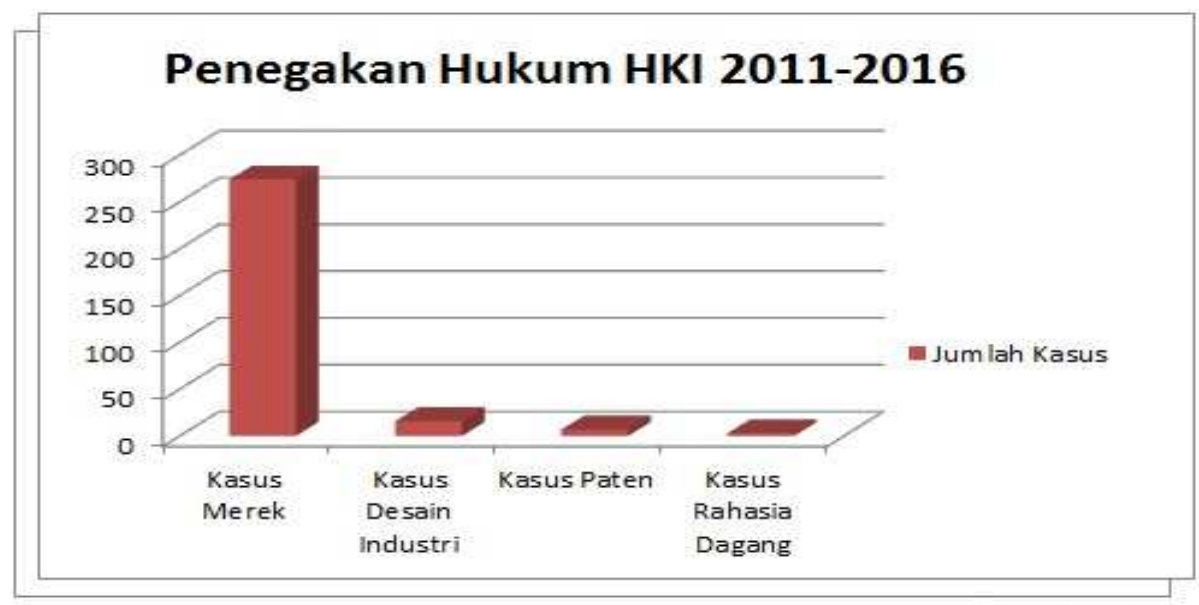

Bisnis Indonesia

Tingginya kasus merek di atas menunjukan bahwa merek mempunyai nilai ekonomis yang tinggi. Produk yang diberi merek merupakan kekayaan immaterial dari perusahaan yang dapat menaikan pendapatan.13 Hal ini sering dimanfaatkan oleh competitor yang memiliki itikad tidak baik untuk mendompleng, membajak, meniru untuk mengambil keuntungan dengan cara yang singkat. ${ }^{14}$

Harus diakui, Indonesia merupakan surga bagi produk-produk bajakan. Selain pendaftaran yang longgar, penegakan hukum yang lemah juga didukung dengan budaya masyarakat yang memilih menggunakan merek-merek terkenal dengan harga murah. Hal ini juga dikarenakan tingkat ekonomi yang tidak bisa disamakan dengan negaranegara maju yang berimbas pula pada daya beli masyarakat. Banyaknya pendaftaran merek yang secara sengaja menyerupai merek terkenal sering mendapatkan legalisasi dari pemerintah. Sehinga pelaku usaha saling bertarung di pengadilan.

\footnotetext{
10 "Pembajakan Hak Intelektual di Indonesia Masuk 4 Besar Dunia" https://www.liputan6.com/news/read/2527345/pembajakan-hak-intelektual-di-indonesia-masuk-4-besar-dunia diakses tanggal 14 April 2018.

11 "Hingga Juni, Terjadi 33 Kasus Pelanggaran Hak Merek Dagang" https://economy.okezone.com/read/2016/06/09/320/1410354/hingga-juni-terjadi-33-kasus-pelanggaran-hakmerek-dagang. Diakses tanggal 14 April 2018.

12 “Ini Dia Tren Kasus Pelanggaran HKI”http://kabar24.bisnis.com/read/20171011/16/697954/inidia-tr diakses tanggal 14 April 2018.

13 OK. Saidin, Aspek Hukum Hak Kekayaan Intelektual (Intellectual Property Right), PT. Rajagrafindo Persada, Jakarta, 1995, hlm. 330.

${ }^{14}$ Durianto, Darmadi, Sugiarto, dan Tony Sitinjak, Strategi Menaklukkan Pasar Melalui Riset Ekuitas Perilaku Merek, Gramedia Utama Pustaka, Jakarta, 2011, hlm. 22.
} 
Persoalan kedua, terkait aspek prosedural dan administratif, pendaftaran merek telah memberikan tuntutan dan patokan yang dielaborasi dalam regulasi tataran teknis. Namun dalam tahapan pemeriksaan substansi, masalahnya menjadi tidak sederhana. Karena yang dimaksud substansi bukan hanya masalah elemen figuratif atau visual untuk menentukan ada persamaan pada pokoknya atau tidak dengan merek lainnya. Lebih dari itu undang-undang mensyaratkan harus adanya motif itikad baik. Permasalahan yang terjadi adalah bagaimana menilai, mengukur, dan memberikan judgement yang tepat terhadap motif itikad tidak baik yang berdimensi persaingan curang. Hal ini menuntut adanya sistem pengawasan pendaftaran merek yang lebih tegas dan lebih tertib.

Motif itikad tidak baik mengemuka dalam lalu lintas perdagangan, baik dalam skala domestik maupun internasional. Konvensi Paris meletakan dasar pengaturan visioner dalam article 6 bis para (1), yang secara konsepsional menetapkan prinsip melarang pendaftaran dan penggunaan merek yang merupakan hasil tiruan. ${ }^{15}$ Namun persoalan pendaftaran merek tersebut dibatasi oleh yurisdiksi keberlakuan merek di negara dimana didaftarkan. ${ }^{16}$ Sehingga memungkinkan terbitnya serifikat merek yang mirip disuatu negara dengan merek di negara lain. Selain itu, bahwa prinsip pendaftaran merek mengacu pada pendaftar pertama (first to file) yang lebih diutamakan dari pada merek yang sudah ada namun belum didaftarkan. ${ }^{17}$

\section{Rumusan Masalah}

Dari penjelasan latar belakang di atas dapat dirumuskan masalah sebagai berikut. Pertama, bagaimanakah konsepsi itikad tidak baik dalam pendaftaran merek di Indonesia? Kedua, bagaimana model penegakan hukum terhadap pendaftran merek dengan itikad tidak baik di Indonesia?

\section{Tujuan Penelitian}

Tujuan dari penelitian ini adalah : Pertama, untuk mengkaji dan memahami konsepsi itikad tidak baik dalam pendaftaran merek di Indonesia ; dan Kedua, untuk mengetahui

15 Paris convention for the Protection of Industrial Property 1883. Article 6 bis para (1):

16 Graeme B. Dinwoodie, "Private International Aspects of The Protection of Trademarks", Makalah, European Community and ASEAN Intellectual Property Rights Co-operation Program- ECAP II, Munchen, 2004, hlm. 57 .

${ }_{17}$ Vania Isura Sitepu, "Pelaksanaan Prinsip First to File Dalam Penyelesaian Sengketa Merek Dagang Asing Di Pengadilan (Studi Kasus tentang Gugatan Pencabutan Hak Merek "TOAST BOX” oleh BreadTalk Pte. Ltd No: 02/Merek/2011/PN. Niaga/Medan)", PREMISE LAW JURNAL 3, 2015, hlm. 3. 
model penegakan hukum terhadap pendaftran merek dengan itikad tidak baik di Indonesia

\section{Metodologi Penelitian}

Penelitian ini adalah penelitian hukum normatif yang mengkaji konsep, kaidah, asas-asas, teori dan peraturan perundang undangan berkaitan dengan dalam pendaftaran merek. ${ }^{18}$ Penelitian ini menggunakan pendekatan undang-undang (statute approach), konsep (conceptual approach) dan kasus (case approach). ${ }^{19}$ Penelitian ini dilakukan dengan cara studi pustaka yang mengkaji teks-teks dokumen hukum untuk selanjutnya dianalisis secara preskriptif dan deskriptif.

\section{Hasil Penelitian dan Pembahasan}

\section{Konsep Itikad Tidak Baik dalam Pendaftaran Merek}

Konsep iktikad tidak baik telah diatur sejak UU Merek 1992, dilanjutkan dengan UU Merek 2001 dan disempurnakan melalui UU Merek 2016. Dimana ketiga undangundang tersebut telah menjelaskan konsep itikad tidak baik dalam pendaftaran merek yaitu Pemohon yang patut diduga dalam mendaftarkan Mereknya secara tidak layak dan tidak jujur untuk meniru, menjiplak, atau mengikuti Merek pihak lain demi kepentingan usahanya menimbulkan kondisi persaingan usaha tidak sehat, mengecoh, atau menyesatkan konsumen.

Penjelasan tentang konsep itikad tidak baik juga dijelaskan dalam beberapa yurisprudensi yaitu Putusan No. 1269 L/Pdt/1984 tanggal 15 Januari 1986, putusan No. 220 PK/Perd/1981 Tanggal 16 Desember 1986 dan putusan No.1272 K/Pdt./1984 tanggal 15 Januari 1987, MA berpendapat bahwa pemilik merek beritikad tidak baik karena telah terbukti menggunakan merek yang sama pada pokoknya atau sama pada keseluruhannya dengan merek pihak lawan.

Patricia Loughlan menyebutkan fungsi merek sebagai badge of origin, a piece of personal property, dan sebagai cultural resource. Sebagai badge of origin, merupakan hak yang sangat penting dalam perdagangan dan memperlihatkan hubungan erat antara produk dengan asal barang. Merek sebagai personal property, menempatkan merek sebagai kekayaan bagi pemilik merek. Sehingga dapat dijual atau melisensikan merek tersebut. Berbagai upaya curang dengan meniru merek pihak lain dimaksudkan untuk mengelabui konsumen agar membeli produk dengan merek tiruan tersebut dan

18 Mukti Fajar ND dan Yulianto Ahmad, Dualisme Penelitian Hukum, Cetakan 1, PT. Raja Grafindo Persada, Yogyakarta, 2010, hlm. 28.

${ }^{19}$ Peter Mahmud, Penelitian Hukum, Cetakan ke-7, Kencana, Jakarta, 2005, hlm. 119. 
mengambil hak ekonominya.20 Selanjutnya merek sebagai cultural resource, juga mempunyai parameter yang valid untuk menilai adanya motif itikad tidak baik dibalik pendaftaran dan kepemilikan merek. ${ }^{21}$ Di Indonesia misalnya akan janggal jika menggunakan merek dengan bahasa Jepang, Korea, atau Arab. Namun karena orang Indonesia menyukai produk dengan merek asing dengan anggapan lebih baik dari merek lokal, sehingga hal ini tetap dilakukan dengan maksud untuk mengelabui masyarakat.

Merek dibuat dari unsur-unsur berupa gambar, logo, nama, kata, huruf, angka, susunan warna, dalam bentuk 2 dimensi dan/atau 3 dimensi, suara, hologram, atau kombinasi dari 2 atau lebih unsur tersebut. ${ }^{22}$ Sehingga kemungkinan terjadinya kemiripan hampir nihil, karena ada milyaran kemungkinan model merek yang bisa dibuat dengan unsur-unsur diatas. Jika terjadi kemiripan pendaftaran merek dapat dipastikan karena niat tidak baik, seperti kasus di bawah ini.
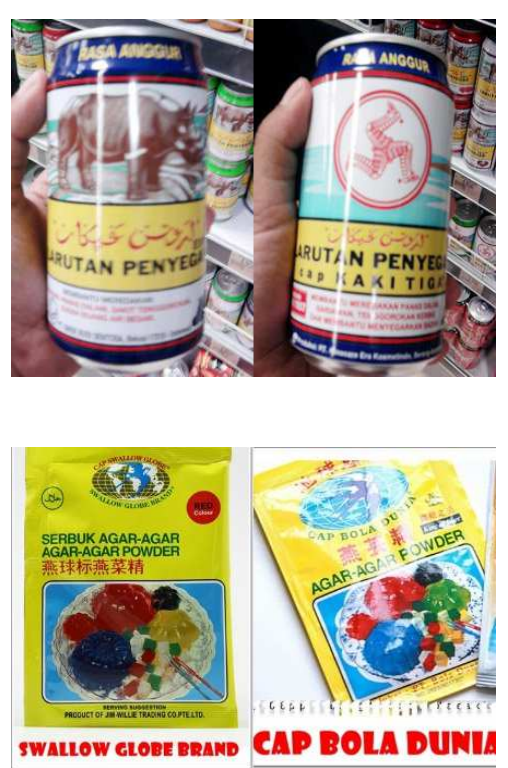

Hakim berpendapat, Budi Yuwono tercatat lebih dulu sebagai pemilik merek larutan penyegar Badak untuk kelas 32 dan 05 yang masing-masing terdaftar dengan nomor IDM000241894 dan IDM000152059. Sedangkan Cap Kaki Tiga dari Singapura terdaftar dengan nomor IDM000241894 dengan kelas yang sama tetapi baru didaftarkan pada tahun 2008 silam. Oleh karena itu, Direktorat HAKI (turut tergugat) harus mencabutnya dari daftar umum merek. ${ }^{23}$

Merek Swallow Globe Brand merupakan merk milik Efendy dengan gambar Bola Dunia (Globe) dan Burung Walet (Swallow) dalam bentuk dan susunan serta warna yang telah terdaftar dalam daftar Umum Merek dengan nomor pendaftaran 361196 tanggal 31 Mei 1996. Kemudian, merk agar-agar Cap Bola Dunia (Blobe) milik Soewardjono dengan gambar Bola Dunia (Globe) dan Burung Walet (Swallow) sebagaimana terdaftar dalam No. 487928 tanggal 31 Agustus 2001 mempunyai persamaan susunan pada pokoknya dengan merek Swallow Globe Brand. ${ }^{24}$

${ }^{20}$ Dalam hukum common law disebut passing off. Lihat Agung Sujatmiko, "Prinsip Hukum Penyelesaian Pelanggaran Passing Off Dalam Hukum Merek", Jurnal Yuridika Vol. 25 No. 1, Januari-April 2010, hlm. 53. Lihat pula Henry Soelistyo, Badfaith Dalam Hukum Merek, Maharsa Artha Mulia, Jakarta, 2016, hlm. 55.

${ }^{21}$ Patricia Loughlan, Intellectual Property: Creative and Marketing Rights, Sydney, 1998, hlm. 18.

${ }^{22}$ Menurut Undang-Undang Nomor 20 Tahun 2016 tentang Merek dan Indikasi Geografis Pasal 1 ayat (1), Merek adalah tanda yang dapat ditampilkan secara grafis berupa gambar, logo, nama, kata, huruf, angka, susunan warna, dalam bentuk 2 (dua) dimensi dan/atau 3 (tiga) dimensi, suara, hologram, atau kombinasi dari 2 (dua) atau lebih unsur tersebut untuk membedakan barang dan/atau jasa yang diproduksi oleh orang atau badan hukum dalam kegiatan perdagangan barang dan/atau jasa.

23 “Drama Perseteruan Cap Badak vs Cap Kaki Tiga Jilid II" https://news.detik.com/berita/ 2083742/drama-perseteruan-cap-badak-vs-cap-kaki-tiga-jilid-ii/2 diakses pada tanggal 13 April 2018.

${ }^{24}$ Lihat bagian pertimbangan dalam Putusan Mahkamah Agung No. 06 K/N/HaKi/2002 
Secara umum jangkauan pengertian itikad tidak baik meliputi perbuatan "penipuan" (fraud), rangkaian "menyesatkan" (misleading) orang lain, serta tingkah laku yang mengabaikan kewajiban hukum untuk mendapat keuntungan. Bisa juga diartikan sebagai perilaku yang tidak dibenarkan secara sadar untuk mencapai suatu tujuan yang tidak jujur (dishonestly purpose). ${ }^{25}$ Demikian pula menurut Black's Law Dictionary, bad faith didefinisikan dengan: the opposite of good faith, generally implying or involving actual or constructive fraud, or a design to mislead or deceive another, or a neglect or refusal to fulfill some duty or some contractual obligation, not prompted by an honest mistake as to one's rights or duties, but by some interested or sinister motive."26

Dalam pengkajian merek, setiap perbuatan peniruan, reproduksi, mengkopi, membajak atau membonceng kemasyuran merek orang lain dianggap sebagai perbuatan pemalsuan, penyesatan atau memakai merek orang lain tanpa hak (unauthorized use) yang secara harmonisasi dalam perlindungan merek dikualifikasikan sebagai persaingan curang (unfair competition) serta dinyatakan sebagai perbuatan mencari kekayaan secara tidak jujur (unjust enrichment). ${ }^{27}$

J. Satrio menjelaskan dua pengertian itikad baik, yaitu itikad baik subjektif dan itikad baik objektif. Itikad baik subjektif (subjectief goeder trow) adalah berkaitan dengan apa yang ada di dalam pikiran manusia, yaitu berkaitan dengan sikap batinnya apakah yang bersangkutan sendiri menyadari bahwa kehendaknya itu bertentangan dengan itikad baik. Itikad baik objektif (objectief goeder trow) adalah kalau pendapat umum mengungkapkan tindakan begitu bertentangan dengan itikad baik. ${ }^{28}$

Pandangan ini selaras dengan kaidah Pasal 1338 ayat (3) KUHPerdata yang mengatur pentingnya itikad baik dalam membuat dan menyusun perjanjian. Asas itikad baik menurut Ismijati berasal dari tatanan konsep hukum Romawi yang disebut Bonafides. Dalam arti subjektif, itikad baik disamakan maknanya dengan kejujuran sedangkan dalam arti objektif disamakan dengan makna kepatutan. ${ }^{29}$

\footnotetext{
25 Agus Mardianto, "Penghapusan Pendaftaran Merek Berdasarkan Gugatan Pihak Ketiga", Jurnal Dinamika Hukum, Unsoed Purwokerto, Vol. 10 No. 1, 2010, Hlm, 47

${ }^{26}$ Bryan A. Garner, Black's Law Dictionary, Eight Edition, United State Of America, 2004.

${ }^{27}$ Ibid. hlm, 179.

${ }^{28}$ J. Satrio, Hukum Perikatan, Perikatan yang Lahir Dari Perjanjian, Bandung: PT Citra Aditya Bakti, 2000,

29 Siti Ismijati Jenie, Itikad Baik Perkembangan dari Asas Hukum Khusus Menjadi Asas Hukum Umum di Indonesia, dalam Pengukuhan Guru Besar UGM, 11 September 2007. http://ugm.ac.id/id/berita/2066pengukuhan.prof.ismijati.jenie.itikad .baik.sebagai.asas.hukum diakses pada tanggal 14 April 2018
} 
Istilah itikad tidak baik dapat ditemukan diberbagai bidang hukum terutama dalam hukum privat. ${ }^{30}$ Adanya itikad tidak baik seringkali dijadikan sebagai dasar dalam melakukan upaya hukum khusus seperti halnya ganti rugi dan upaya pembatalan suatu perjanjian. ${ }^{31}$ Selain itu itikad tidak baik berperan sebagai "gap-filling"32 untuk memberikan perlindungan hukum yang berkeadilan didalam hukum yang bersifat tertulis untuk memberikan ruang atau upaya hukum apabila terjadi kecurangan. Walaupun frasa "itikad tidak baik" seringkali ditemui didalam peraturan perundangundangan, namun bentuk dan konsepnya sendiri merupakan suatu hal yang sulit ditentukan. Bahkan menurut A.D Mitchell, asas itikad tidak baik maupun itikad baik merupakan asas tersulit untuk dikonsepsikan dari semua asas hukum internasional.33

Pembagian itikad tidak baik secara subjektif dan objektif sebagaimana dikemukakan oleh J. Satrio merupakan formulasi klasik yang berorientasi pada keadaan mental berkaitan dengan ketidakjujuran (dishonesty) dan ketulusan (sincerly). Akan tetapi dalam perkembangannya terutama dibidang hukum bisnis, asas itikad tidak baik juga dikaitan dengan disloyalty atau ketidaksetiaan dan ketidakpatuhan. ${ }^{34}$ Sehingga disini menurut hemat penulis, konsep itidak tidak baik dalam pendaftaran merek merupakan perbuatan yang berawal dari ketidaktulusan (insincerity) dan ketidakjujuran (dishonesty) yang kemudian disertai dengan tipu muslihat (deceit) sehingga menimbulkan ketidakpatuhan (disloyalty) terhadap hukum.

Berkaitan dengan hukum merek, itikad tidak baik dijelaskan dalam Pasal 21 ayat (3) UU Merek $2016^{35}$ bahwa permohonan ditolak jika diajukan oleh pemohon yang beritikad tidak baik. Begitupun menurut UU Merek $2001^{36}$ dalam Pasal 4 menegaskan, merek tidak dapat didaftarkan atas dasar permohonan yang diajukan oleh pemohon yang beritikad tidak baik. Kemudian dalam UU Merek 1992,37 Pasal 4 ayat (1) dikatakan, merek hanya dapat didaftarkan atas dasar permintaan pemilik merek yang beritikad baik.

${ }^{30}$ Lawrence Ponoroff \& F. Stephen Knippenberg, The Implied Good Faith Filing Require-ment: Sentinel of an Evolving Bankruptcy Policy, 85 NW. U. L. REV. 1991, page. 919, 970-971. (“The term 'good faith' is a workhorse in the legal vocabulary.... Good faith has been called upon in radically disparate contexts to establish the outer boundaries of acceptable behavior.").

31 Joseph K. Leahy, A Decade After Disney: A Primer on Good and Bad Faith, 83 U. CIN. L. REV. (2015). page.898-901.

32 Paul MacMahon, Good Faith and Fair Dealing as an Underenforced Legal Norm, 99 MINN. L. REV (2015) page.2051,2060.

33 Andrew D. Mitchell, Good Faith in WTO Dispute Settlement, 7 MELB. J. INT'L L. (2006) psge. 339, 344 . ("Of all the principles of international law, it has been claimed, the principle of good faith is perhaps the hardest to define.")

34 David E.Pozen, Constitutional Bad Faith, Harvard Law Review, Volume 129, No.4, February (2016) page. 892,893

35 Undang-Undang Nomor 20 Tahun 2016 tentang Merek dan Indikasi Geografis

36 Undang-Undang Nomor 15 Tahun 2001 tentang Merek

${ }^{37}$ Undang-Undang Merek Nomor 19 Tahun 1992 tentang Merek 
Selanjutnya penjelasan Pasal 21 ayat (3) UU Merek 2016 disebutkan : "Pemohon yang beriktikad tidak baik" adalah Pemohon yang patut diduga dalam mendatarkan Mereknya memiliki niat untuk meniru, menjiplak, atau mengikuti Merek pihak lain demi kepentingan usahanya menimbulkan kondisi persaingan usaha tidak sehat, mengecoh, atau menyesatkan konsumen. Mahkamah Agung memiliki frasa yang jelas mengenai presumptions yaitu "sulit dibayangkan adanya itikad lain selain mendompleng popularitas merek pihak lain". Berbanding dengan frasa tersebut, maka tindakan mendompleng merek orang lain berarti melakukan tindakan yang didasari dengan itikad tidak baik. 38

Sebagai perbandingan, di Amerika Serikat mewajibkan agar merek didaftarkan dengan bonafide atau itikad baik, akan tetapi tidak menjabarkan seperti apa itikad baik yang dimaksudkan. Proses pendaftaran merek dimulai dengan memasukan permohonan yang kemudian dilanjutkan dengan pemeriksaan substantif oleh $\underline{\text { United States Patent and }}$ Trademark Office (USPTO) dan attorney. Selama proses dilakukan dengan memeriksa apakah merek yang didaftarkan memiliki kesamaan dengan merek lain berikut pemeriksaan administratif. Apabila merek yang diajukan oleh pemohon sudah lolos pemeriksaan substantif. Maka merek akan diumumkan selama 30 hari dan setelah itu pemohon akan diberikan surat persetujuan oleh USPTO. Selanjutnya dengan pemohon mengisi surat yang berisi Statement of Use (SoU) guna melihat apakah ada itikad tidak baik dalam pendaftaran tersebut. Setelah SoU diperiksa dan disetujui maka pendaftaran merek telah selesai. ${ }^{39}$

Sedangkan di Singapore pendaftaran merek relatif lebih mudah dengan 4 proses yakni: (1) permohonan; (2) pemeriksaan; (3) pemumuman; dan (4) sertifikasi. Akan tetapi berbeda halnya dengan Indonesia dan Amerika Serikat yang masa pengumumannya hanya 30 hari, berdasarkan hukum Singapore pengumuman dilakukan selama 60 hari untuk melihat adanya pengaduan unsur bad faith dalam merek yang didaftarkan. ${ }^{40}$

Itikad tidak baik dalam pendaftaran merek dapat dijadikan sebagai alasan pembatalan merek menurut Undang-Undang Merek. Alasan terjadinya suatu pembatalan pendaftaran merek yang didasarkan pada persamaan pada pokoknya sama dengan yang dibuktikan pada itikad baik dalam suatu gugatan pembatalan terhadap pendaftaran merek.

\footnotetext{
${ }^{38}$ Henry Soelistyo, Loc. Cit.

${ }^{39}$ Anonim, https://www.uspto.gov/trademarks-getting-started/trademark-process\#step6 diakses pada tanggal 15 April 2018

${ }^{40}$ Anonim, https://www.ipos.gov.sg/protecting-your-ideas/trade-mark/application-process diakses pada tanggal 15 April 2018
} 


\section{Model Penegakan Hukum Terhadap Bad Faith dalam Pendaftaran Merek}

Permasalahan itikad tidak baik dalam pendaftaran merek sudah seharusnya mendapatkan pengawasan oleh pemerintah. Peran dari pemerintah untuk mencegah terjadinya pendaftaran merek dengan motif itikad tidak baik menjadi sangat strategis, karena proses ini akan dilakukan pengecekan atas pendaftaran merek untuk menentukan terbitnya sertifikat kepemilikan merek. Dimana pemegang sertifikat merek adalah bukti satu-satunya kepemilikan yang sah dan kuat secara hukum. Pemerintah dalam hal ini Dirjen HKI menjadi pintu pertama sekaligus terakhir dari legalisasi kepemilikan merek. Oleh karena itu, fungsi pengawasan menjadi sangat penting untuk mengeliminir terjadikan kemiripan merek sebelum mendapatkan kekuatan hukum yang sah pada saat diterbitkan sertifikat.

Sistem perlindungan merek di Indonesia menggunakan sistem konstitutif first to files). Kelebihan dari sistem first to files adalah terjaminnya kepastian hukum dengan sertifikasi bagi pemilik merek untuk tujuan komersial. Akan menjadi masalah ketika pihak-pihak yang bersengketa tersebut sama-sama memiliki sertifikat merek yang terdaftar. Oleh karena itu, pemeriksaan dan pengawasan tidak hanya sebelum proses sertifikasi tetapi juga setelah merek tersebut terdaftar sehingga tidak menimbulkan pemboncengan merek terkenal. ${ }^{41}$

Pengawasan terkait prinsip itikad tidak baik di Indonesia memiliki konsep yang sama seperti halnya pada pendaftaran di Amerika Serikat, Australia, dan Jepang.42 Sepanjang proses pendaftaran merek, dilakukan pada saat pengumuman selama 2 bulan untuk melihat apakah ada pihak yang keberatan dengan pendaftaran tersebut dan apabila tidak ada keberatan setelah 30 hari sejak pengumuman akan dilaksanakan pemeriksaan substantif selama kurang lebih 150 hari oleh Direktorat Jendral Kekayaan Intelektual sebelum akhirnya diterima dan mendapat sertifikasi. ${ }^{43}$ Setelah itu masih ada pengawasan lebih lanjut terhadap merek yang sudah didaftarkan. Apabila ada merek-merek yang diketahui memenuhi unsurunsur itikad buruk dapat dilakukan penghapusan maupun pembatalan berdasarkan pengaduan dan gugatan dari pemilik merek terdaftar yang merasa dirugikan sebagaimana Pasal 72 sampai dengan Pasal 79 UU Merek 2016.

Setidaknya ada beberapa hal penting dari metode pengawasan pendaftaran merek, yaitu:

${ }^{41}$ Emmy Yuhassari, Hak Kekayaan Intelektual dan Perkembangannya, Jakarta: Pusat Pengkajian Hukum, 2004, hlm. 206-207.

${ }^{42}$ Bandingkan Prosedur Pendaftaran Merek pada DJKI (Indonesia) http://www.dgip.go.id/, IP Australia https://www.ipaustralia.gov.au, USPTO (Amerika Serikat) https://www.uspto.gov/, JPO (Jepang) https://www.jpo.go.jp/ diakses pada tanggal 13 April 2018

43 http:/ / www.dgip.go.id/prosedur-diagram-alir-permohonan-merek, diakses pada 13 April 2018 
a. Tahapan administrastif: berupa kelengkapan persyaratan pendaftaran berikut gambar yang jelas, pihak yang mengajukan dan kelas produk.

b. Tahapan pengecekan persamaan: yaitu proses pelacakan merek yang didaftarkan dengan merek terdaftar dan merek terkenal. Ini tahap yang penting untuk diawasi, sehingga memerlukan dukungan teknologi untuk mengkonfirmasi merek yang didaftarkan dengan merek yang sudah ada apakah memiliki daya pembeda

c. Tahapan pengumuman: tahap dimana merek disosialisasikan untuk mendapatkan respon dari masyarakat. Sebagai upaya rechecking oleh dunia usaha atas hasil pelacakan sebelumnya oleh pemerintah.

d. Tahapan legalisasi merek: adalah akhir proses pendaftaran merek dengan diterbitkannya sertifikat merek. Tahap ini akan menentukan keabsahan dari suatu merek dengan segala hak yang melekat.

Berikut adalah diagram alir (flow chart) pengawasan serta upaya pembatalan sebelum dan sesudah sertifikasi berdasarkan UU Merek 2016:

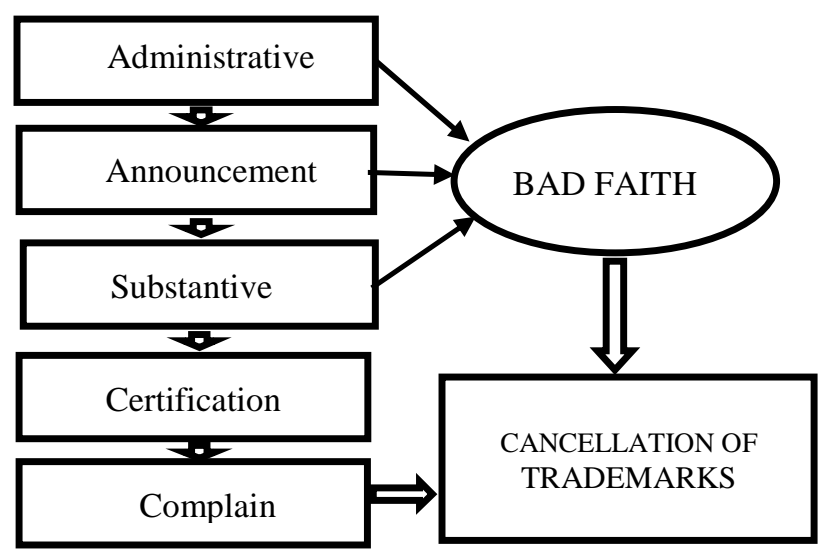

Bandingkan dengan diagram alir pengawasan serta upaya pembatalan sebelum dan sesudah sertifikasi di Amerika Serikat berdasarkan USPTO

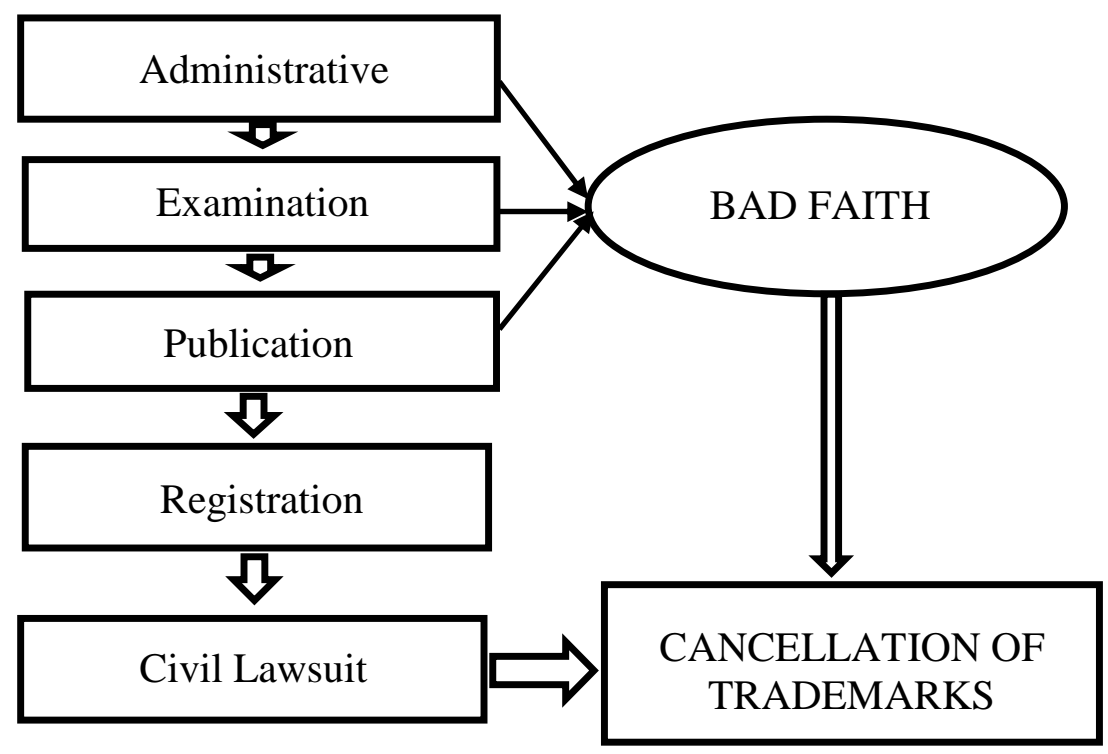


Undang-undang merek beserta penjelasannya telah memadai sebagai arahan dalam pelaksaaan pendaftaran merek. Namun masih banyak pemilik merek yang merasa dirugikan karena pelaksanaanya tidak objektif, kolutif, penuh dengan rekayasa di tingkat teknik dan administratif. ${ }^{44}$ Dari kasus-kasus yang telah diputus pengadilan tampak terlalu luasnya ruang interpretasi arti "persamaan pada pokoknya", sehingga menjadi sangat subjektif dan tidak terukur.

Penghapusan merek terdaftar dapat diajukan atas prakarsa Menteri atau oleh pemilik merek yang bersangkutan kepada Menteri. Selain itu penghapusan merek atas prakarsa Menteri hanya dapat dilakukan setelah mendapatkan rekomendasi dan Komisi Banding Merek.45 Penghapusan merek terdaftar dapat pula diajukan oleh pihak ketiga yang berkepentingan dalam bentuk gugatan ke Pengadilan Niaga dengan alasan merek tersebut tidak digunakan selama 3 tahun berturut-turut dalam perdagangan barang dan/atau jasa sejak tanggal pendaftaran atau pemakaian terakhir. ${ }^{46}$

Sedangkan pembatalan merek dilakukan dengan cara gugatan ke Pengadilan Niaga oleh pihak berkepentingan apabila ada muatan itikad tidak baik pada merek tersebut. ${ }^{47}$

Gugatan pembatalan memiliki daluwarsa paling lama 5 tahun terhitung sejak didaftarkannya merek. Namun, gugatan pembatalan dapat diajukan tanpa batas waktu jika terdapat unsur itikad tidak baik. ${ }^{48}$ Sehingga pemilik merek yang merasa dirugikan dapat mengajukan gugatan pembatalan walaupun baru mengetahui merek tersebut dilanggar setelah waktu yang lama.

Gugatan pembatalan merek terdaftar yang dilakukan oleh pihak ketiga harus melihat siapa sebenarnya yang memiliki itikad buruk, karena filosofi pendaftaran merek adalah perlawanan terhadap itikad tidak baik.49 Sehingga kepemilikan dan pemakaian merek itupun harus dilakukan dengan itikad yang baik (good faith) agar pemilik

${ }^{44}$ Henry Soelistyo, Op. Cit., hlm. 16.

45 Pasal 72 Undang-Undang No. 20 Tahun 2016 Tentang Merek dan Indikasi Geografis.

46 Alasan merek tidak digunakan sebagaimana dimaksud diatas tidak berlaku dalam hal adanya larangan impor, larangan yang berkaitan dengan izin bagi peredaran barang yang menggunakan merek yang bersangkutan atau keputusan dari pihak yang berwenang yang bersifat sementara, dan larangan serupa lainnya yang ditetapkan dengan Peraturan Pemerintah dan ketentuan ini berlaku secara mutatis mutandis terhadap penghapusan $\mathrm{m}^{\text {erek }} \mathrm{k}^{\text {olektif terdaftar...lihat Pasal }}$ 74 dan 75 Undang-Undang No. 20 Tahun 2016 Tentang Merek dan Indikasi Geografis. Geografis.

47 Pasal 76 Undang-Undang Negara Republik Indonesia No. 20 Tahun 2016 tentang Merek dan Indikasi

48 Pasal 77 Undang-Undang Negara Republik Indonesia No. 20 Tahun 2016 tentang Merek dan Indikasi Geografis.

49 Hendy Soelistyo, op. cit, hlm. 42-43. lihat juga Agus Mardianto, Penghapusan Pendaftaran Merek Berdasarkan Gugatan Pihak Ketiga, Jurnal Dinamika Hukum, Vol. 10 No. 1 Januari 2010, hlm. 45. 
mendapatkan perlindungan hak ekonominya. ${ }^{0}$ Filosofi ini dapat dilihat di Statute of Queen Anne (1710), yaitu memberikan hak ekonomi kepada penulis-penulis sastra dengan memberikan insentif beasiswa. ${ }^{51}$ Juga pada undang-undang Roman Venetian tahun $1474,{ }^{52}$ memberikan insentif bagi para pemikir untuk mendorong kreativitas dan inovasi.53 Brian Patterson dan Dennis Karjala mengatakan bahwa penegakan hukum di bidang HKI menggunakan pendekatan kepentingan umum (public-benefit).54 Pendekatan public-benefit atau instrumentalist membutuhkan pembentukan aturan yang dapat menyeimbangkan antara perlindungan yang berkaitan dengan kekayaan intelektual di satu sisi dan kebebasan berkarya di sisi lainnya. ${ }^{55}$ Jika suatu merek kemungkinannya akan menimbulkan kerugian bagi masyarakat pada umumnya, merek tersebut ditolak pendaftarannya. 56

Pada praktik penegakan merek di Indonesia seringkali terjadi pemboncengan merek atau yang dikenal dengan istilah passing off. Para pesaing curang (unfair competitor) memanfaatkan kesalahan memilih produk di masyarakat (public misleading). ${ }^{57}$ Maka dari itu, Direktorat Jendral Kekayaan Intelektual (DJKI) memiliki peran penting dalam melakukan pemeriksaan apakah ada itikad tidak baik yang mendorong atau menjadi motif dari pendaftaran tersebut sebelum menyetujuinya.

Penegakan hukum atas pendaftaran merek dengan iktikad tidak baik dilakukan dengan beberapa model : (a) penolakan merek sejak proses pendaftaran jika terdapat persamaan pada pokoknya; (b) Upaya penghapusan merek terdaftar yang oleh pemilik merek yang bersangkutan kepada Menteri atau dapat dilakukan atas prakarsa Menteri serta oleh pihak ketiga yang berkepentingan dengan gugatan ke Pengadilan Niaga ; (c)

50 Cita Citrawinda P., Perlindungan Merek Terkenal Di Indonesia, Makalah disampaikan pada program pelatihan "Training of Teachers" angkatan VIII yang diselenggarakan oleh Fakultas Hukum Universitas Indonesia tanggal 23 Nopember 2000. hlm.34-39.

51 Elizabeth Judge and Daniel Gervais, Intellectual Property: The Law in Canada, 2nd edn, Carswell, 2011,

52 Catherine Colston and Jonathan Galloway, Modern Intellectual Property Law, 3rd edn, Routledge, 2010, hlm. 2.

53 William M Landes and Richard A Posner, "An Economic Analysis of Copyright Law", 18 Journal of Legal Studies 325, 1989; William M Landes and Richard A Posner, The Economic Structure of Intellectual Property Law, HUP, 2003, hlm.11-36.

54 Brian Paterson and Dennis Karjala, "Looking Beyond Intellectual Property in Resolving Protection of the Intangible Cultural Heritage of Indigenous Peoples" Cardozo Journal of International and Comparative Law (2003) 11, hlm. 633, 647-648.

${ }^{55}$ Freedom-Kai Phillips, "Intellectual Property Rights in Traditional Knowledge: Enabler of Sustainable Development" Utrecht Journal of International and European Law, 32(83), hlm. 1-18. DOI: http://doi.org/10.5334/ujiel.283.

56 Ahmadi Miru, Hukum Merek “Cara Mudah Mempelajari Undang-Undang Merek”, PT. Raja Grafindo Persada, Jakarta, 2005, hlm. 20.

${ }^{57}$ Nur Hidayati, "Perlindungan Hukum Pada Merek Yang Terdaftar," Jurnal Pengembangan Humaniora Vol. 11 No. 3, Desember 2011, hlm. 178...lihat juga Erma Wahyuni, T. Saiful Bahri, Hessel Nogi S. Tangkilisan, Kebijakan dan Manajemen Hukum Merek, Yogyakarta: YPAPI, Tanpa Tahun, hlm. 99 
Upaya pembatalan merek dilakukan dengan cara gugatan ke Pengadilan Niaga oleh pihak berkepentingan dengan batas waktu daluarsa. Tetapi gugatan pembatalan dapat diajukan tanpa batas waktu jika terdapat unsur iktikad tidak baik.

\section{Penutup}

Dari pembahasan di atas dapat disimpulkan sebagai berikut: Pertama, larangan pendaftaran merek dengan iktikad tidak baik telah diatur sejak UU Merek 1992, dilanjutkan dengan UU Merek 2001 dan disempurnakan melalui UU Merek 2016. Dimana ketiga Undang-Undang tersebut telah menjelaskan konsep itikad tidak baik dalam pendaftaran merek yaitu Pemohon yang patut diduga dalam mendaftarkan Mereknya secara tidak layak dan tidak jujur untuk meniru, menjiplak, atau mengikuti Merek pihak lain demi kepentingan usahanya menimbulkan kondisi persaingan usaha tidak sehat, mengecoh, atau menyesatkan konsumen. Kedua, penegakan hukum atas pendaftaran merek dengan itikad tidak dilakukan dengan model : (a) penolakan merek sejak proses pendaftaran jika terdapat persamaan pada pokoknya; (b) Upaya penghapusan merek terdaftar yang oleh pemilik merek yang bersangkutan kepada Menteri atau dapat dilakukan atas prakarsa Menteri serta oleh pihak ketiga yang berkepentingan dengan gugatan ke Pengadilan Niaga ; (c ) Upaya pembatalan merek dilakukan dengan cara gugatan ke Pengadilan Niaga oleh pihak berkepentingan dengan batas waktu daluarsa. Tetapi gugatan pembatalan dapat diajukan tanpa batas waktu jika terdapat unsur iktikad tidak baik.

\section{Daftar Pustaka}

\section{Buku Buku}

Astriani, Dwi Sri Rezki, Penghapusan Merek Terdaftar, PT Alummi, Bandung, 2009.

Colston, Catherine and Jonathan Galloway, Modern Intellectual Property Law, 3rd edn, Routledge, 2010.

Durianto, Darmadi, Sugiarto, dan Tony Sitinjak, Strategi Menaklukkan Pasar Melalui Riset Ekuitas Perilaku Merek, Gramedia Utama Pustaka, Jakarta, 2011.

Djumhana, Muhammad dan R. Djubaedillah, Hak Kekayaan Intelektual, Sejarah, Teori dan Prakteknya di Indonesia, Citra Aditya Abadi, Bandung, 1997.

Fajar ND, Mukti, dan Yulianto Ahmad, Dualisme Penelitian Hukum, Cetakan 1, PT. Raja Grafindo Persada, Yogyakarta, 2010.

Judge, Elizabeth, and Daniel Gervais, Intellectual Property: The Law in Canada, 2nd edn, Carswell, 2011.

Landes, William M., and Richard A Posner, The Economic Structure of Intellectual Property Law, HUP, 2003.

Loughlan, Patricia, Intellectual Property: Creative and Marketing Rights, Sydney, 1998. 
Mahmud, Peter, Penelitian Hukum, Cetakan ke-7, Kencana, Jakarta, 2005.

Miru, Ahmadi, Hukum Merek "Cara Mudah Mempelajari Undang-Undang Merek", PT. Raja Grafindo Persada, Jakarta, 2005.

Muhammad, Abdul Kadir, Kajian Hukum Ekonomi Hak Kekayaan Intelektual, Citra Aditya, Bandung, 2001.

Saidin, OK., Aspek Hukum Hak Kekayaan Intelektual (Intellectual Property Right), PT. Rajagrafindo Persada, Jakarta, 1995.

Satrio, J., Hukum Perikatan, Perikatan yang Lahir Dari Perjanjian, PT Citra Aditya Bakti, Bandung, 2000.

Soelistyo, Henry, Badfaith Dalam Hukum Merek, Maharsa Artha Mulia, Jakarta, 2016.

Wahyuni, Erma, T. Saiful Bahri, Hessel Nogi S. Tangkilisan, Kebijakan dan Manajemen Hukum Merek, Yogyakarta, YPAPI, Tanpa Tahun.

Yuhassari, Emmy, Hak Kekayaan Intelektual dan Perkembangannya, Pusat Pengkajian Hukum, Jakarta, 2004.

\section{Peraturan Perundang-undangan}

Kitab Undang-Undang Hukum Perdata

Undang-Undang Nomor 19 Tahun 1992 tentang Merek (Lembaran Negara Republik Indonesia Tahun 1992 Nomor 81)

Undang-undang Nomor 15 Tahun 2001 tentang Merek (Lembaran Negara Republik Indonesia Tahun 2001 Nomor 110)

Undang-Undang Republik Indonesia Nomor 20 Tahun 2016 tentang Merek dan Indikasi Geografis (Tambahan Lembaran Negara Republik Indonesia Nomor 5953)

\section{Makalah/Jurnal/Penelitian}

Andrew D. Mitchell, “Good Faith in WTO Dispute Settlement”, 7 MELB. J. INT'L L, 2006.

Citrawinda P., Cita, "Perlindungan Merek Terkenal Di Indonesia", Makalah disampaikan pada program pelatihan "Training of Teachers" angkatan VIII yang diselenggarakan oleh Fakultas Hukum Universitas Indonesia tanggal 23 Nopember 2000.

David E. Pozen, "Constitutional Bad Faith", Harvard Law Review, Volume 129, No.4, February, 2016.

Dinwoodie, Graeme B., "Private International Aspects of The Protection of Trademarks", Makalah, European Community and ASEAN Intellectual Property Rights Co-operation Program- ECAP II, Munchen, 2004.

Effendi, Murawi, "Pengalaman Kepolisian dalam Penyidikan Pelanggaran Hak Merek", Makalah, Disampaikan dalam Seminar Nasional Perlindungan Hukum Merek dalam Era Persaingan Global, kerjasama Fakultas Hukum UII, Yayasan Klinik HaKI Jakarta, dan JETRO, 3 Maret 1999, Yogyakarta.

Hidayati, Nur, "Perlindungan Hukum Pada Merek Yang Terdaftar", Jurnal Pengembangan Humaniora Vol. 11 No. 3, Desember 2011.

Jenie, Siti Ismijati, "Itikad Baik Perkembangan dari Asas Hukum Khusus Menjadi Asas Hukum Umum di Indonesia", dalam Pengukuhan Guru Besar UGM, 11 September 2007. 
Leahy, Joseph K. “A Decade After Disney: A Primer on Good and Bad Faith”, $83 U$. CIN. L. REV. 2015.

Landes, William M. and Richard A Posner, "An Economic Analysis of Copyright Law" (1989) 18 Journal of Legal Studies 325.

Mamahit, Jisia, "Perlindungan Hukum Atas Merek Dalam Perdagangan Barang Dan Jasa", Lex Privatum, Volume, 1. No. 3. Juli 2013.

Mardianto, Agus, "Penghapusan Pendaftaran Merek Berdasarkan Gugatan Pihak Ketiga", Jurnal Dinamika Hukum, Vol. 10 No. 1 Januari 2010.

Nasution, Nurhayati, “Analisis Yuridis Pertimbangan Hakim Tentang Pembatalan Merek Terdaftar GS Gold Shine", Tesis, Surakarta, Universitas Sebelas Maret, 2011.

Paterson, Brian and Dennis Karjala, "Looking Beyond Intellectual Property in Resolving Protection of the Intangible Cultural Heritage of Indigenous Peoples" (2003) 11 Cardozo Journal of International and Comparative Law 633.

Paul MacMahon, Good Faith and Fair Dealing as an Underenforced Legal Norm, 99 MINN. L. REV, 2015.

Philips, Freedom-Kai, “Intellectual Property Rights in Traditional Knowledge, Enabler of Sustainable Development", Utrecht Journal of International and European Law. 32(83), pp.1-18. DOI: http://doi.org/10.5334/ujiel.283

Ponoroff, Lawrence \& F. Stephen Knippenberg, “The Implied Good Faith Filing Requirement: Sentinel of an Evolving Bankruptcy Policy", 85 NW. U. L. REV. 1991.

Sitepu, Vania Isura, "Pelaksanaan Prinsip First to File Dalam Penyelesaian Sengketa Merek Dagang Asing Di Pengadilan (Studi Kasus tentang Gugatan Pencabutan Hak Merek "TOAST BOX" oleh BreadTalk Pte. Ltd No: 02/Merek/2011/PN. Niaga/Medan)", Premise Law Jurnal 3, 2015.

Sujatmiko, "Prinsip Hukum Penyelesaian Pelanggaran Passing Off Dalam Hukum Merek", Jurnal Yuridika Vol. 25 No. 1, Januari-April 2010.

\section{Internet}

Rini Komalasari, Analisis Yuridis Terhadap Sengketa Kepemilikan Merek "Lexus" Antara Perusahaan PT. Toyota Jidosha Kabushiki Kaisa dengan PT. Lexus Lexus Daya Utama (Studi Kasus Putusan No. 194.K/Pdt/Sus/2011, https://media.neliti.com/media/publications/162016-ID-analisis-yuridisterhadap-sengketa-kepem.pdf

Siti Ismijati Jenie, Itikad Baik Perkembangan dari Asas Hukum Khusus Menjadi Asas Hukum Umum di Indonesia, dalam Pengukuhan Guru Besar UGM, 11 September 2007, http://ugm.ac.id/id/berita/2066-pengukuhan.prof.ismijati.jenie.itikad .baik.sebagai.asas.hukum diakses pada tanggal 14 April 2018

DJKI (Indonesia) http:/ / www.dgip.go.id/ diakses pada tanggal 13 April 2018

IP Australia https:/ /www.ipaustralia.gov.au diakses pada tanggal 13 April 2018

IPOS (Singapore) https://www.ipos.gov.sg/protecting-your-ideas/trade-mark/applica tion-process diakses pada tanggal 15 April 2018

USPTO (Amerika Serikat) https:/ / www.uspto.gov/ diakses pada tanggal 13 April 2018 
https://www.uspto.gov/trademarks-getting-started/trademark-process\#step6 diakses pada tanggal 15 April 2018

JPO (Jepang) https:/ /www.jpo.go.jp/. diakses pada tanggal 13 April 2018

http://www.dgip.go.id/prosedur-diagram-alir-permohonan-merek diakses pada tanggal 13 April 2018

"Drama Perseteruan Cap Badak vs Cap Kaki Tiga Jilid II", https://news.detik.com/berita/2083742/drama-perseteruan-cap-badak-vs-capkaki-tiga-jilid-ii/2 diakses pada tanggal 13 April 2018.

"Lewat Lima Tahun, Gugatan Pembatalan Merek tak Bisa Diajukan", http:/ / www.hukumonline.com/berita/baca/hol14409/lewat-lima-tahungugatan-pembatalan-merek-tak-bisa-diajukan diakses pada tanggal 14 April 2018

"5 Kasus Unik Sengketa Merek Dagang di Indonesia", https://news.detik.com/berita/d1966282/5-kasus-unik-sengketa-merek-dagang-di-indonesia/3 diakses pada tanggal 14 April 2018

"Pembajakan Hak Intelektual di Indonesia Masuk 4 Besar DUnia", https://www.liputan6.com/news/read/2527345/pembajakan-hak-intelektualdi-indonesia-masuk-4-besar-dunia diakses pada tanggal 14 April 2018

"Hingga Juni, Terjadi 33 Kasus Pelanggaran Hak Merek Dagang", https:/ /economy.okezone.com/read/2016/06/09/320/1410354/hingga-juniterjadi-33-kasus-pelanggaran-hak-merek-dagang diakses pada tanggal 14 April 2018.

"Ini Dia Tren Kasus Pelanggaran HKI", http://kabar24.bisnis.com/read/ 20171011/16/697954/ini-dia-tr diakses pada tanggal 14 April 2018

https://www.uspto.gov/trademarks-getting-started/trademark-process\#step6 diakses pada tanggal 15 April 2018.

https://www.ipos.gov.sg/protecting-your-ideas/trade-mark/application-process diakses pada tanggal 15 April 2018. 